\title{
Anopheles ziemanni a locally important malaria vector in Ndop health district, north west region of Cameroon
}

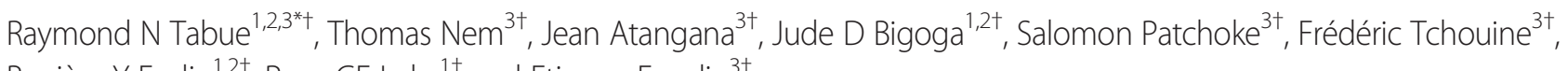
Barrière Y Fodjo ${ }^{1,2+}$, Rose GF Leke ${ }^{1+}$ and Etienne Fondjo ${ }^{3+}$

\begin{abstract}
Background: Malaria transmission in Cameroon is mediated by a plethora of vectors that are heterogeneously distributed across the country depending on the biotope. To effectively guide malaria control operations, regular update on the role of local Anopheles species is essential. Therefore, an entomological survey was conducted between August 2010 and May 2011 to evaluate the role of the local anopheline population in malaria transmission in three villages of the Ndop health district in the northwest region of Cameroon where malaria is holoendemic, as a means to acquiring evidence based data for improved vector intervention.
\end{abstract}

Methods: Mosquitoes were sampled both indoor and outdoor for four consecutive nights in each locality during each month of survey. Sampling was done by the human landing catch method on volunteers. Anopheles species were identified morphologically and their ovaries randomly dissected for parity determination. Infection with Plasmodium falciparum was detected by Circumsporozoite protein ELISA. Members of An. gambiae complex were further identified to molecular level by PCR and RFLP PCR.

Results: An. ziemanni was the main malaria vector and whether outdoor or indoor. The man biting rate for the vectors ranged from 6.75 to 8.29 bites per person per night $(\mathrm{b} / \mathrm{p} / \mathrm{n})$. The entomological inoculation rate for this vector species was 0.0278 infectious bites per person per night (ib/p/n) in Mbapishi, $0.034 \mathrm{ib} / \mathrm{p} / \mathrm{n}$ in Mbafuh, and $0.063 \mathrm{ib} / \mathrm{p} / \mathrm{n}$ in Backyit. These were by far greater than that for An. gambiae. No difference was observed in the parity rate of these two vectors. PCR analysis revealed the presence of only An. colluzzi (M-form).

Conclusions: An. ziemanni is an important local malaria vector in Ndop health district. The findings provide useful baseline information on the anopheles species composition, their distribution and role in malaria transmission that would guide the implementation of integrated vector management strategies in the locality.

Keywords: Malaria, Anopheles ziemanni, Anopheles gambiae, Cameroon

\section{Background}

Malaria remains a serious health problem in sub-Saharan Africa, affecting mainly children less than five years old and expectant mothers [1]. In Cameroon about $40 \%$ of all deaths in children less than five years old are due to malaria [2]. Thanks to the intensifying efforts by control

\footnotetext{
* Correspondence: tnraymon@yahoo.fr

${ }^{\dagger}$ Equal contributors

'National Reference Unit for Vector Control, The Biotechnology Center, University of Yaoundé I, P.O. Box 3851-Messa, Yaoundé, Cameroon

${ }^{2}$ Faculty of Science, Department of Biochemistry, University of Yaoundé I, P.O. Box 812, Yaoundé, Cameroon

Full list of author information is available at the end of the article
}

programmes in scaling-up the intervention strategies, the current global trends indicate a decline in the malaria morbidity and mortality by about fifty percent between 2000 and 2010 [1]. Nevertheless, this decrease in the number of malaria cases and deaths is not homogenous as most parts of the country remain highly endemic to malaria. This is linked to several factors which encompass the evolution and spread of drug resistance in the parasite, insecticide resistance in the vectors and the presence of a vast plethora of vectors species. These vectors are also unevenly distributed with differential efficiencies 
in mediating malaria transmission across the different endemic micro environments [3-9].

Knowledge of the vector profile in a given epidemiologic scenario is an important step to the planning and implementation of effective vector intervention strategies. Therefore, the acquisition of information on the local Anopheles population, their spatial distribution and contribution to malaria transmission is mandatory such that measures taken would be readily amenable to intervention.

About forty eight species of Anopheles have been identified in Cameroon [10-12] of which at least fourteen are reported to support the development and propagation of human Plasmodia. Amongst these are five major vectors, namely Anopheles (cellia) gambiae Giles, 1902; Anopheles funestus Giles, 1900; Anopheles arabiensis Patton, 1905; Anopheles nili (Theobald), 1904; Anopheles moucheti moucheti Evans, 1925 and at least nine secondary vectors (Anopheles paludis Theobald, 1900; Anopheles carnavalei Brunhes, le Goff \& Geoffroy, 1998; Anopheles coustani Laveran, 1900; Anopheles marshallii (Theobald), 1903; Anopheles ziemanni Gruenberg, 1902; Anopheles pharoensis Theobald, 1901; Anopheles hancocki, Edwards 1929; Anopheles wellcomei wellcomei Theobald, 1904; Anopheles (cellia) ovengensis) [13-17]. To date, there is insufficient knowledge on the bionomic and role of these secondary vectors in the malaria transmission in many areas of the country. Their occurrence, abundance and composition tend to vary greatly with the eco-epidemiological setting. In fact, Cameroon is characterized by a southern forested equatorial zone where transmission is perennial, a northern Sudanian savannah zone with a long (five to six months) seasonal transmission pattern, and a sahelian savannah zone of the far north with very short (about 3 months) seasonal transmission $[2,3,5]$. Depending on the setting, the vectors may be sympatric or occur in isolation mediating transmission either at the same time or at different times.

Ndop health district is a specific ecological area in the north western savannah of Cameroon. It is characterized by paddy fields that are irrigated by water sourcing from numerous natural lakes in the vicinity. Such lakes are known to be prolific for Anopheles (especially An. ziemanni) breeding that upholds transmission in such locality. However, there is no existing information on the mosquito species composition and their role in malaria transmission in Ndop. Therefore, this study sought to primarily characterize the mosquito fauna and determine the role of anophelines in the transmission of malaria in the locality.

\section{Methods}

\section{Description of the study site}

The study was carried out in Ndop Health District, situated $06^{\circ} 00^{\prime} \mathrm{N}, 10^{\circ} 42^{\prime} \mathrm{E}$ in the Northwest Region of Cameroon (Figure 1). The climate is characterized by a long rainy season (June to November) with rainfall averaging
$1800-2500 \mathrm{~mm}$ per year, average relative humidity of $97 \%$ to $98 \%$ and mean annual temperature of $24^{\circ} \mathrm{C}$. Cross sectional surveys were carried out during the peak of the rainy season (August-November) and during three months of the dry season (January, April and May). Three villages in Ndop Health District were selected: Mbafuh, Mbapishi and Backyit.

Mbafuh and Mbapishi belong to Bambalang health area and are characterized by their proximity to the Bamendjim Lake. This lake creates wetlands that are actively occupied for agriculture. Its population is estimated at 19,000 inhabitants dispersed in 4 villages. Backyit is the main village of Balikumbat health with a population of about 23,133 inhabitants. In these three villages, agriculture is the main economic activity with rice cultivation being commonest practice in the wetlands of its plains.

\section{Adult mosquito sampling}

Mosquito sampling took place simultaneously in the three villages belonging to two health areas (Backyit in Balikumbat health area, Mbafuh and Mbapishi in Bambalang health area). Human landing collections were performed during four consecutive nights from 06:00 pm-06:00 am each month. Mosquitoes were collected indoors and outdoors in three randomly selected houses (at least $50 \mathrm{~m}$ apart) and rotating between houses at different locations in each village each night. A team of two trained volunteers per house; one sitting inside the house and the other on the veranda collected female mosquitoes as they landed on exposed lower limbs, making a total of 24 human-nights per month per village. The volunteers changed collection points (indoor or outdoor) every two hours in order to minimize bias. Ethical clearance was obtained from the National ethics committee of Cameroon ( $\mathrm{N}^{\circ}$ : FWA IRB00001954). Consent from household heads was sought prior to using the house for mosquito collection. Participation in mosquito collection was strictly voluntary and only those adequately trained on the collection procedures were retained.

\section{Field processing of mosquitoes}

Anopheles mosquitoes collected were sorted and identified morphologically using the identification keys of Gillies and de Meillon [18] and Gillies and Coetzee [19]. Anopheline species were randomly dissected and the ovaries examined to determine parity as described previously [20]. The carcasses of both the dissected and non-dissected anopheline mosquitoes were individually stored desiccated in labeled Eppendorf tubes containing silica gel for subsequent laboratory analyses.

\section{Laboratory processing of anophelines}

The head-thorax portion of each mosquito was homogenized in blocking buffer (0.5\% Casein, $0.1 \mathrm{~N} \mathrm{NaOH}$, 


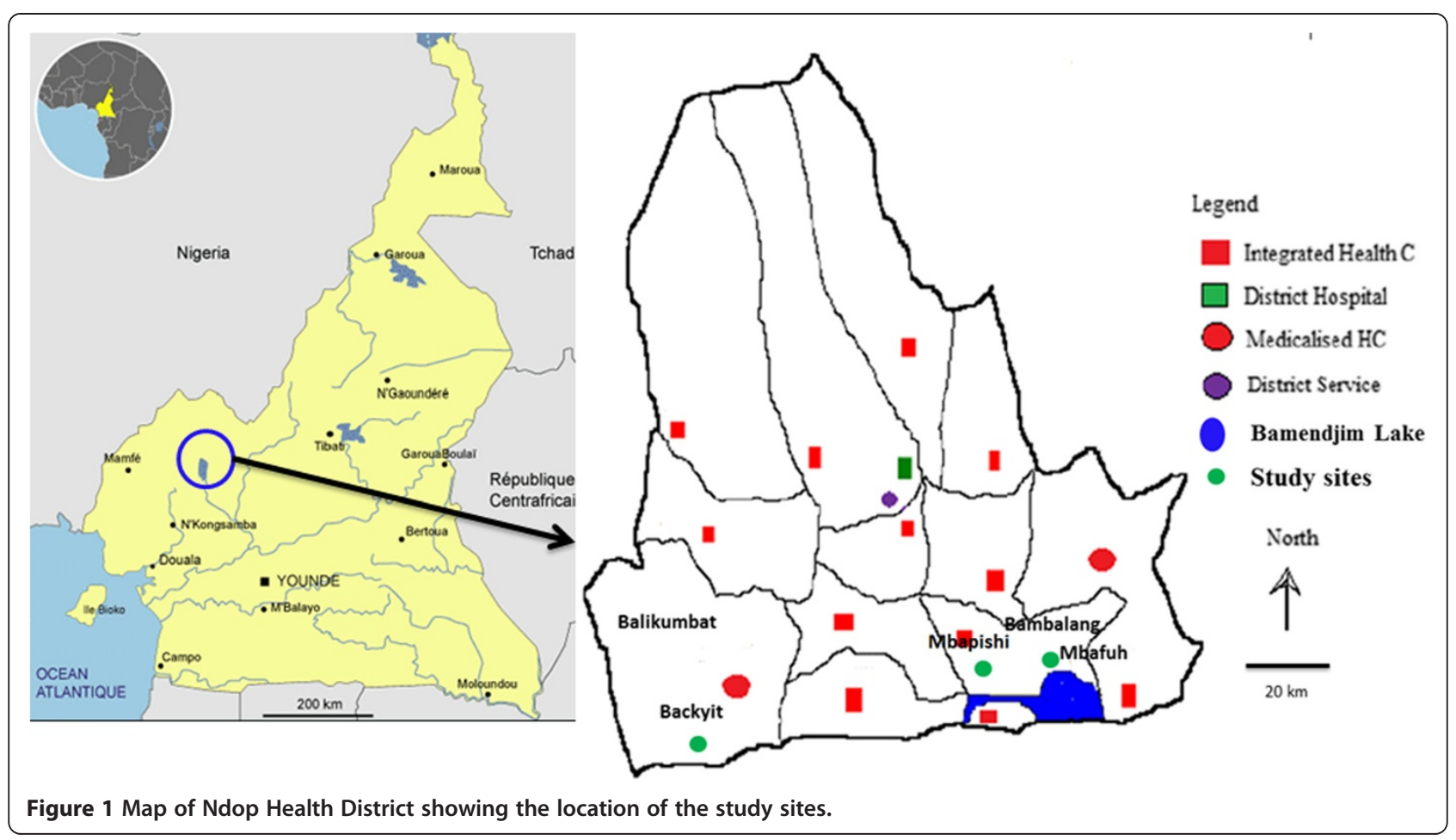

$1 \times \mathrm{PBS}$ ) and used to check for the presence of Plasmodium falciparum Circumsporozoite antigen (CSA) by ELISA previously [21,22]. A positive control (Kikergaard \& Perry Laboratories, USA) and negative controls (uninfected laboratory reared mosquitoes) were tested along with the rest of the samples. A sample was considered positive if the optical density of the resulting green coloration visualized at $405 \mathrm{~nm}$ was greater than the mean of those of the negative controls plus three times the standard deviation. The head-thorax portions of the mosquitoes were used to guard against overestimating the infection rates.

Mosquitoes belonging to An. gambiae s.l were randomly selected for molecular identification. DNA was extracted from the legs and wings of selected mosquitoes by the method described by Collins et al., 1987 [23]. The extracted DNA was suspended in $25 \mu \mathrm{l}$ of sterile TE buffer (10 mMTris - $\mathrm{HCl} \mathrm{pH} \mathrm{8.1,} 1 \mathrm{mM}$ EDTA) and used to identify An. gambiae siblings by PCR [24]. The presence of the $\mathrm{M}$ and $\mathrm{S}$ molecular forms of An. gambiae s.s was determined by restriction fragment length polymorphism (RFLP) of ribosomal DNA [22].

\section{Data analysis}

Data of the four consecutive nights of sampling in each village and per month were calculated. The following entomological indices were calculated: the man biting rate (m.a), which represents the average number of bites received per person per night; the Infection Rate (IR), that measured the proportion of mosquitoes positive for P. falciparum CSA by ELISA; the Parity rate, which is the ratio of parous mosquitoes to the overall dissected; Entomological Inoculation Rate (EIR) which is the number of infective bites received per person per night; EIR is calculated as the product of the m.a and IR. Data were analyzed using SPSS Statistics software version 17.0 and the Kruskal Wallis test was used to compare means at 95\% confidence interval.

\section{Results}

\section{Mosquito composition}

A total of 33,739 mosquitoes were collected during our study. The proportion of anophelines collected from the three villages ranged from $10.23 \%$ to $13.26 \%$ (Table 1). Nuisance was mainly caused by Aedes Sp, Coquillettidia $S p$, Culex Sp, and Mansonia Sp. The density of Mansonia $S p$ was very high in the three villages and varied from $45.9 \%$ to $83.47 \%$ of the total culicines collected. Mansonia $S p$ and Culex $S p$ were the dominant culicine mosquitoes in the three study sites with a highest density of $83.47 \%$ observed in Mbafuh (Table 1). Aedes Sp was present at a low density and only 112 mosquitoes were collected, none was collected from Mbapishi. Coquillettidia $S p$ was also present, but at low densities. Anopheles species represented $12.05 \%, 10.23 \%$ and $13.26 \%$ of the total mosquito population in Backyit, Mbafuh, and Mbapishi respectively.

Anopheles diversity and abundance in the study localities The anopheline population collected varied from one site to another and some species were common to all the sites. In the three villages, An. ziemanni and An. gambiae s.l 
Table 1 Composition of the Culicine fauna in Backyit, Mbafuh and Mbapishi August 2010 September 2010 October 2010 November 2010 January 2011 April 2011 May 2011 Total Percentage Backyit

\begin{tabular}{|c|c|c|c|c|c|c|c|c|c|}
\hline Anopheles Sp & 104 & 144 & 380 & 644 & 217 & 8 & 55 & 1552 & $12.05 \%$ \\
\hline Aedes Sp & 16 & 14 & 0 & 0 & 0 & 7 & 72 & 109 & $0.85 \%$ \\
\hline Coquillettidia Sp & 0 & 0 & 0 & 5 & 1 & 0 & 2 & 8 & $0.06 \%$ \\
\hline Culex Sp & 1763 & 877 & 841 & 408 & 410 & 236 & 765 & 5300 & $41.14 \%$ \\
\hline Mansonia Sp & 264 & 1101 & 1360 & 1357 & 338 & 370 & 1124 & 5914 & $45.91 \%$ \\
\hline Total & 2147 & 2136 & 2581 & 2414 & 966 & 621 & 2018 & 12883 & $100.00 \%$ \\
\hline \multicolumn{10}{|l|}{ Mbafuh } \\
\hline Anopheles Sp & 11 & 150 & 366 & 379 & 241 & 9 & 12 & 1168 & $10.23 \%$ \\
\hline Aedes Sp & 0 & 1 & 1 & 0 & 0 & 0 & 0 & 2 & $0.02 \%$ \\
\hline Coquillettidia Sp & 2 & 6 & 16 & 11 & 4 & 1 & 0 & 40 & $0.35 \%$ \\
\hline Culex Sp & 204 & 117 & 93 & 50 & 195 & 8 & 10 & 677 & $5.93 \%$ \\
\hline Mansonia Sp & 992 & 1693 & 2022 & 1695 & 1265 & 416 & 1443 & 9526 & $83.47 \%$ \\
\hline Total & 1209 & 1967 & 2498 & 2135 & 1705 & 434 & 1465 & 11413 & $100.00 \%$ \\
\hline \multicolumn{10}{|l|}{ Mbapishi } \\
\hline Anopheles Sp & 96 & 237 & 375 & 237 & 233 & 54 & 20 & 1252 & $13.26 \%$ \\
\hline Aedes Sp & 0 & 0 & 0 & 0 & 0 & 0 & 0 & 0 & $0.00 \%$ \\
\hline Coquillettidia Sp & 0 & 4 & 12 & 1 & 5 & 1 & 0 & 23 & $0.24 \%$ \\
\hline Culex Sp & 268 & 126 & 137 & 167 & 101 & 3 & 10 & 812 & $8.60 \%$ \\
\hline Mansonia Sp & 953 & 1235 & 1110 & 1571 & 1063 & 251 & 1173 & 7356 & $77.90 \%$ \\
\hline Total & 1317 & 1602 & 1634 & 1976 & 1402 & 309 & 1203 & 9443 & $100.00 \%$ \\
\hline
\end{tabular}

were the dominant vector species. A total of $187 \mathrm{An}$. gambiae as compared to 3697 An. ziemanni were collected in all three sites (Table 2).

In Backyit, 06 Anopheles species were encountered. $A n$. ziemanni represents $90 \%$ of anopheline species collected while $A n$. gambiae represented $8 \%$. The other species (An. funestus, An. christyi, An. pharoensis, An. moucheti, $A n$. rufipes, and $A n$. implexus) represented just 2\% of this population. About $97 \%$ and $93 \%$ of anopheline species collected respectively in Mbafuh and Mbapishi was composed of An. ziemanni (Table 2). In total, 12 Anopheles species were collected in the three villages with a high density of $A n$. ziemanni that varied from $89.82 \%$ to 97.09\%. This was followed by An. gambiae s.l. Other species were either absent or were at low densities, varying from one village to another. PCR analysis of An. gambiae complex revealed that the entire An. gambiae s.l population was made up of $A n$. gambiae s.s. and only the $\mathrm{M}$ form was present in the three villages.

\section{Variation in the biting rate, feeding behavior and entomological inoculation rate of An. gambiae and An. ziemanni}

Anopheles ziemanni was the most aggressive species with a man-bite rate of 8.29 bites per person per night $(\mathrm{b} / \mathrm{p} / \mathrm{n})$ in Backyit, $6.75 \mathrm{~b} / \mathrm{p} / \mathrm{n}$ in Mbafuh and $6.96 \mathrm{~b} / \mathrm{p} / \mathrm{n}$ in Mbapishi (Figure 2). When compared to An. gambiae, the difference in aggressivity in the three villages was significant $(\mathrm{p}<0.05)$. However, the man biting rate of $A n$. gambiae was at times higher than that of An. ziemanni (August 2010, January 2011 in Backyit and April 2011 in Mbapishi) (Table 3).

Table 3 shows the variation in the entomological inoculation rates (EIR) of the two local vectors species during the survey months. The number of infectious bites a person would receive per night was observed to vary between $0.028 \mathrm{ib} / \mathrm{p} / \mathrm{n}$ and $0.058 \mathrm{ib} / \mathrm{p} / \mathrm{n}$ for An. ziemanni. While the EIR for An. gambiae s.l was $0.008 \mathrm{ib} / \mathrm{p} / \mathrm{n}$ in Backyit (Figure 3a), this species did not contribute to transmission in the other villages. Backyit also recorded the highest combined EIR for An. gambiae and An. ziemanni during the survey compare to Mbafuh and Mbapishi (Figure 3b, c).

The biting behaviour of the two species varied between the villages and from one month to another. In general, there was no difference in the biting preference for $A n$. ziemanni and An. gambiae s.l in Backyit and Mbafuh (Figure 4). The difference was however higher for the two species in Mbapishi where they were strongly exophagic. In general, An. ziemanni had the highest density in all three study sites and was observed to bite mainly outdoor compared to indoor. This difference was more pronounced in Mbapishi where the density was 785 
Table 2 Anopheles diversity and abundance

\begin{tabular}{|c|c|c|c|c|c|c|c|c|c|c|c|c|c|c|c|c|c|}
\hline \multirow[b]{2}{*}{ Anopheline species } & \multicolumn{2}{|c|}{ August 2010} & \multicolumn{2}{|c|}{ September 2010} & \multicolumn{2}{|c|}{ October 2010} & \multicolumn{2}{|c|}{ November 2010} & \multicolumn{2}{|c|}{ January 2011} & \multicolumn{2}{|c|}{ April 2011} & \multicolumn{2}{|c|}{ May 2011} & \multicolumn{2}{|c|}{ Total } & \multirow{2}{*}{$\begin{array}{c}\text { Total } \\
\text { Outdoor + Indoor }\end{array}$} \\
\hline & Outdoor & Indoor & Outdoor & Indoor & Outdoor & Indoor & Outdoor & Indoor & Outdoor & Indoor & Outdoor & Indoor & Outdoor & Indoor & Outdoor & Indoor & \\
\hline \multicolumn{18}{|c|}{ Backyit } \\
\hline An. gambiae s.l. & 21 & 35 & 19 & 14 & 1 & 6 & 2 & 2 & 3 & 0 & 4 & 3 & 7 & 5 & 57 & 65 & $122(7.86 \%)$ \\
\hline An. ziemanni. & 24 & 20 & 55 & 54 & 174 & 199 & 367 & 273 & 111 & 79 & 1 & 0 & 25 & 12 & 757 & 637 & 1394 (89.82\%) \\
\hline An. christyi & 2 & 0 & 0 & 0 & 0 & 0 & 0 & 0 & 0 & 0 & 0 & 0 & 0 & 0 & 2 & 0 & $2(0.13 \%)$ \\
\hline An. implexus & 1 & 1 & 0 & 1 & 0 & 0 & 0 & 0 & 15 & 7 & 0 & 0 & 2 & 2 & 18 & 11 & 29 (1.87\%) \\
\hline An. nili & 0 & 0 & 1 & 0 & 0 & 0 & 0 & 0 & 0 & 0 & 0 & 0 & 0 & 0 & 1 & 0 & $1(0.06 \%)$ \\
\hline An. maculipalpis & 0 & 0 & 0 & 0 & 0 & 0 & 0 & 0 & 1 & 1 & 0 & 0 & 1 & 1 & 2 & 2 & $4(0.26 \%)$ \\
\hline TOTAL & 48 & 56 & 75 & 69 & 175 & 205 & 369 & 275 & 130 & 87 & 5 & 3 & 35 & 20 & 837 & 715 & 1552 \\
\hline \multicolumn{18}{|l|}{ Mbafuh } \\
\hline An. gambiae s.l. & 0 & 0 & 1 & 1 & 0 & 0 & 0 & 0 & 0 & 1 & 0 & 0 & 3 & 2 & 4 & 4 & $8(0.68 \%)$ \\
\hline An. ziemanni. & 6 & 5 & 85 & 63 & 200 & 163 & 190 & 188 & 103 & 131 & 0 & 0 & 0 & 0 & 584 & 550 & 1134 (97.09\%) \\
\hline An. christyi & 0 & 0 & 0 & 0 & 0 & 0 & 0 & 0 & 0 & 0 & 5 & 3 & 4 & 2 & 9 & 5 & $14(1.20 \%)$ \\
\hline An. implexus & 0 & 0 & 0 & 0 & 0 & 0 & 1 & 0 & 3 & 2 & 0 & 0 & 0 & 0 & 4 & 2 & $6(0.51 \%)$ \\
\hline An. tenebrosus & 0 & 0 & 0 & 0 & 1 & 2 & 0 & 0 & 0 & 1 & 0 & 1 & 0 & 0 & 1 & 4 & $5(0.43 \%)$ \\
\hline An. funestus & 0 & 0 & 0 & 0 & 0 & 0 & 0 & 0 & 0 & 0 & 0 & 0 & 1 & 0 & 1 & 0 & $1(0.09 \%)$ \\
\hline TOTAL & 6 & 5 & 86 & 64 & 201 & 165 & 191 & 188 & 106 & 135 & 5 & 4 & 8 & 4 & 603 & 565 & 1168 \\
\hline \multicolumn{18}{|l|}{ Mbapishi } \\
\hline An. gambiae s.l. & 1 & 1 & 0 & 0 & 0 & 0 & 0 & 0 & 0 & 1 & 50 & 0 & 1 & 3 & 52 & 5 & 57 (4.55\%) \\
\hline An. ziemanni. & 56 & 35 & 134 & 102 & 272 & 99 & 158 & 69 & 153 & 71 & 3 & 1 & 9 & 7 & 785 & 384 & 1169 (93.37\%) \\
\hline An. christyi & 1 & 0 & 1 & 0 & 3 & 1 & 7 & 1 & 7 & 1 & 0 & 0 & 0 & 0 & 19 & 3 & 22 (1.76\%) \\
\hline An. implexus & 0 & 0 & 0 & 0 & 0 & 0 & 1 & 1 & 0 & 0 & 0 & 0 & 0 & 0 & 1 & 1 & $2(0.16 \%)$ \\
\hline An. pharoensis & 1 & 1 & 0 & 0 & 0 & 0 & 0 & 0 & 0 & 0 & 0 & 0 & 0 & 0 & 1 & 1 & $2(0.16 \%)$ \\
\hline TOTAL & 59 & 37 & 135 & 102 & 275 & 100 & 166 & 71 & 160 & 73 & 53 & 1 & 10 & 10 & 858 & 394 & 1252 \\
\hline
\end{tabular}




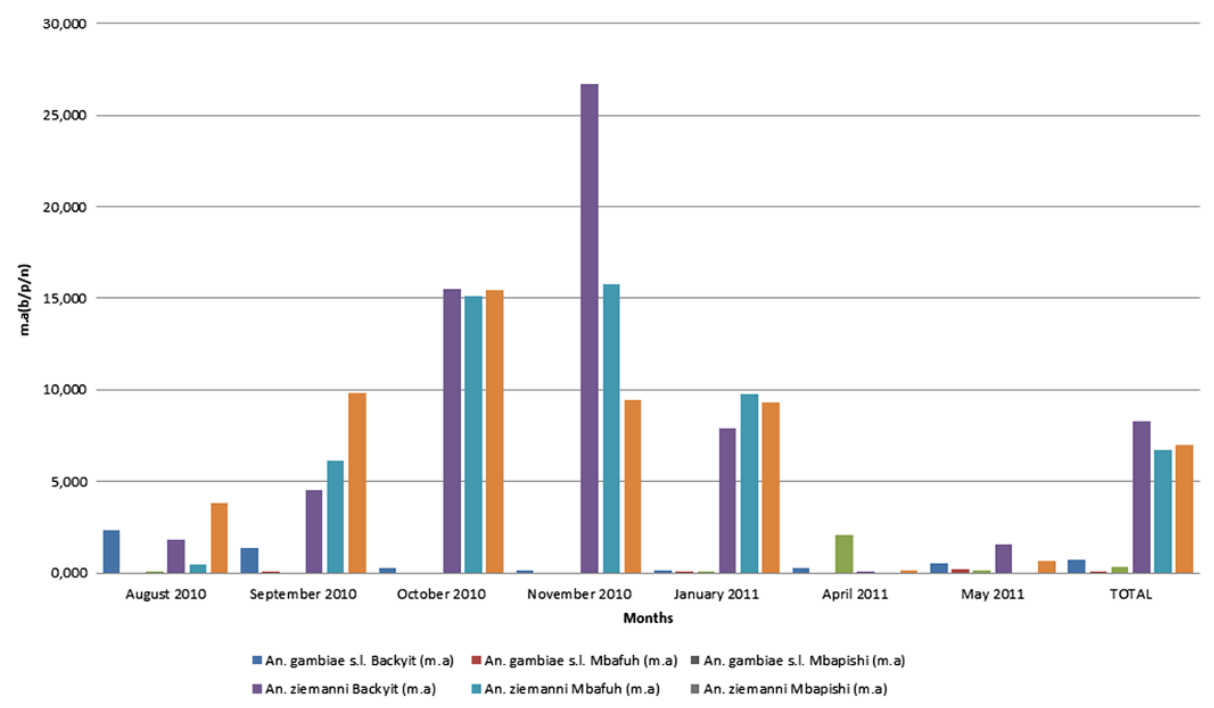

Figure 2 Anopheline man biting rate in Backyit, Mbafuh and Mbapishi. m.a: man biting rate, b/p/n: bites per person per night.

outdoor and 389 indoor for An. ziemanni and 52 outdoor and 5 indoor for An. gambiae s.l (Figure 4). The difference in indoor and outdoor proportion of An. ziemanni in the three villages was significant $(\mathrm{p}<0.05)$.

Following the dissection and examination of the ovaries, An. gambiae and An. ziemanni showed high parity rates in all three villages. However, the low density of An. gambiae did not allow for any statistical comparison of its parity to that of An. ziemanni. For the two vector species, the parity rate varied between $61.11 \%$ and $93.02 \%$ in Backyit, 39.93\% and 78.05\% in Mbafuh and from 19\% and $81 \%$ in Mbapishi. The monthly variations were not significant $(\mathrm{p}>0.05)$.

\section{Discussion}

Successfully controlling malaria compels the implementation of effective vector intervention strategies. Because of climate change and vector dynamics, it is required that a continuous update on the vectors be made, to assess their contribution to malaria transmission such that measures taken are readily amenable for intervention in any given epidemiological setting. The present study aimed at acquiring baseline information on the spatial distribution and contribution of the malaria vectors to transmission in the health district of Ndop, in the Northwest region of Cameroon.

Studies in most parts of the equatorial forested areas of Cameroon, An. gambiae s.l have been reported as the main vector species with playing only minor secondary role in malaria transmission. For the first time An. ziemanni is portrayed here to be the primary vector species with Anopheles gambiae relegated to playing the role of a secondary vector in the Ndop health district. Generally, the densities of mosquitoes collected during the peak of rainy season are more important compare to the dry season. This can be example by the number of breeding site more important during the rainy season. The identification of up to twelve different Anopheles species in this locality is not surprising and only confirms the extensive and complex plethora of the Anopheles fauna already demonstrated and thriving in varied ecological settings of the country $[5,11,25,26]$. Thus, the results show that An. ziemanni was the most abundant Anopheles species during the period of the study in the different sites and is responsible for maintaining transmission even in the absence of the other vectors; this phenomenon is analogous to observations in western Kenya where in the presence of other vectors, An. ziemanni were found have the highest Plasmodium falciparum infection rates [27]. The high density of An. ziemanni was probably a consequence of the ecosystem that enables the proliferation of breeding sites contributing to its development. Indeed, a study to assess the density of breeding sites in these villages revealed that the surroundings natural lakes and other flowing streams were suitable breeding sources for An. ziemanni. It turned out that the selected sites were located near lakes created by the Bamendjim dam.

Overall, the transmission intensity was low as shown by the entomological inoculation rates, despite high density of An. ziemanni, the major vector species in the three villages. This is likely due to the high LLIN coverage $(67.3 \%)$ in the region after the mass campaign and free distribution of LLIN [2]. Indeed, several studies across sites in Africa have demonstrated the efficacy of LLIN to reduce the malaria burden and transmission at the 
Table 3 Variation in the Entomological Inoculation Rate (EIR) for An. gambiae and An. ziemanni

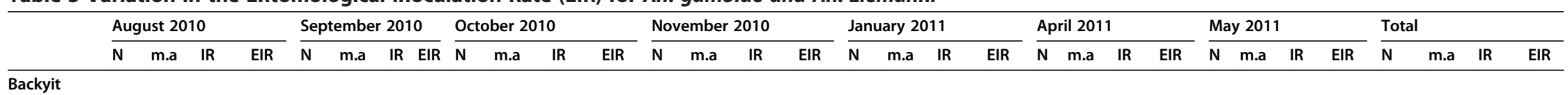

$\begin{array}{llllllllllllllllllllllllllllllllllll}\text { An. gambiae } & 56 & 2.333 & 0.02 & 0.047 & 33 & 1.375 & 0 & 0 & 7 & 0.292 & 0 & 0 & 4 & 0.167 & - & - & 3 & 0.125 & 0 & 0 & 7 & 0.292 & 0 & 0 & 12 & 0.5 & 0 & 0 & 122 & 0.726 & 0.011 & 0.008\end{array}$

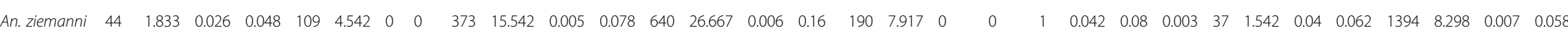

$\begin{array}{lllllllllllllllllllllllllllllllllll}\text { Total } & 100 & 4.167 & 0.022 & 0.092 & 142 & 5.917 & 0 & 0 & 380 & 15.833 & 0.005 & 0.079 & 644 & 26.833 & 0.006 & 0.161 & 193 & 8.042 & 0 & 0 & 8 & 0.333 & 0.03 & 0.01 & 49 & 2.042 & 0.03 & 0.061 & 1516 & 9.024 & 0.007 & 0.063\end{array}$

Mbafuh

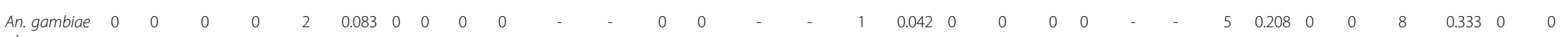

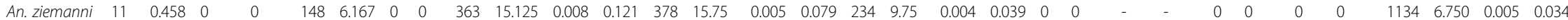
$\begin{array}{llllllllllllllllllllllllllllllllllll}\text { Total } & 11 & 0.458 & 0 & 0 & 150 & 6.25 & 0 & 0 & 363 & 15.125 & 0.008 & 0.121 & 378 & 15.75 & 0.005 & 0.079 & 235 & 9.792 & 0.004 & 0.039 & 0 & 0 & - & - & 5 & 0.208 & 0 & 0 & 1142 & 6.798 & 0.005 & 0.034\end{array}$

\section{Mbapishi}

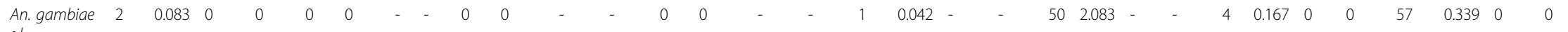

$\begin{array}{llllllllllllllllllllllllllllllllll}\text { An. ziemanni } & 91 & 3.792 & 0 & 0 & 236 & 9.833 & 0 & 0 & 371 & 15.458 & 0.008 & 0.124 & 227 & 9.458 & 0.004 & 0.038 & 224 & 9.333 & 0.004 & 0.037 & 4 & 0.167 & 0 & 0 & 16 & 0.667 & 0 & 0 & 1169 & 6.958 & 0.004 & 0.028\end{array}$

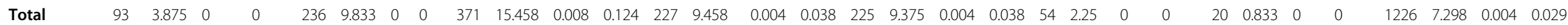

N: number of mosquitoes collected; m.a: man biting rate (aggressivity); IR: Infection Rate; EIR: Entomological Inoculation Rate. 

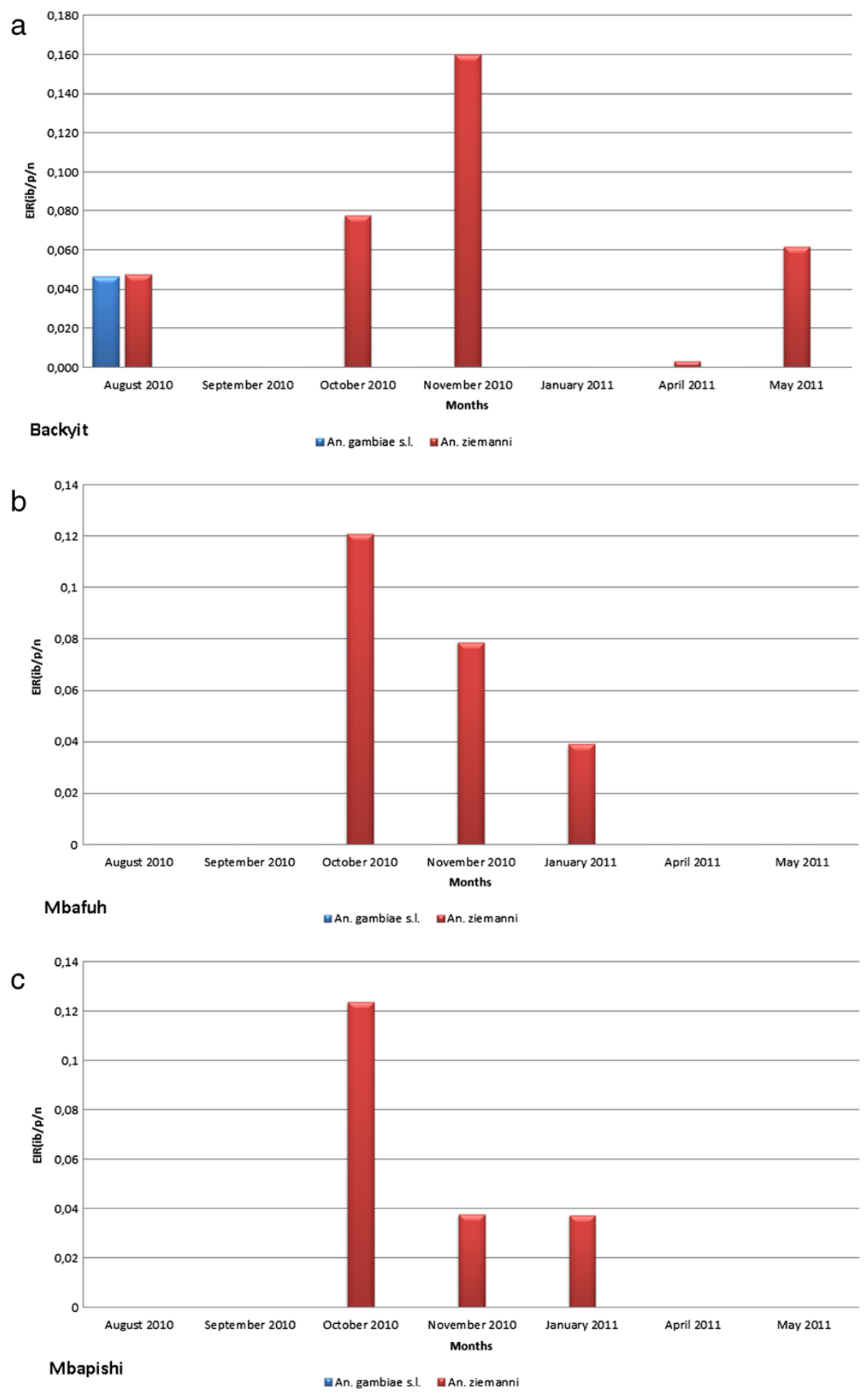

Figure 3 An. ziemanni and An. gambiae EIR variation in Backyit, Mbafuh and Mbapishi. a. EIR variation of An. ziemanni and An. gambiae in Backyit. b - ElR variation of An. ziemanni and An. gambiae in Mbafuh. c - EIR variation of An. ziemanni and An. gambiae in Mbapishi.

community level [28]. However, though not uncommon, this low transmission despite the high parity rates observed might be due to low vector anthropophily, implying An. ziemanni may be feeding on hosts other than human. This will be investigated further. This species however, has been previously reported to play a secondary 


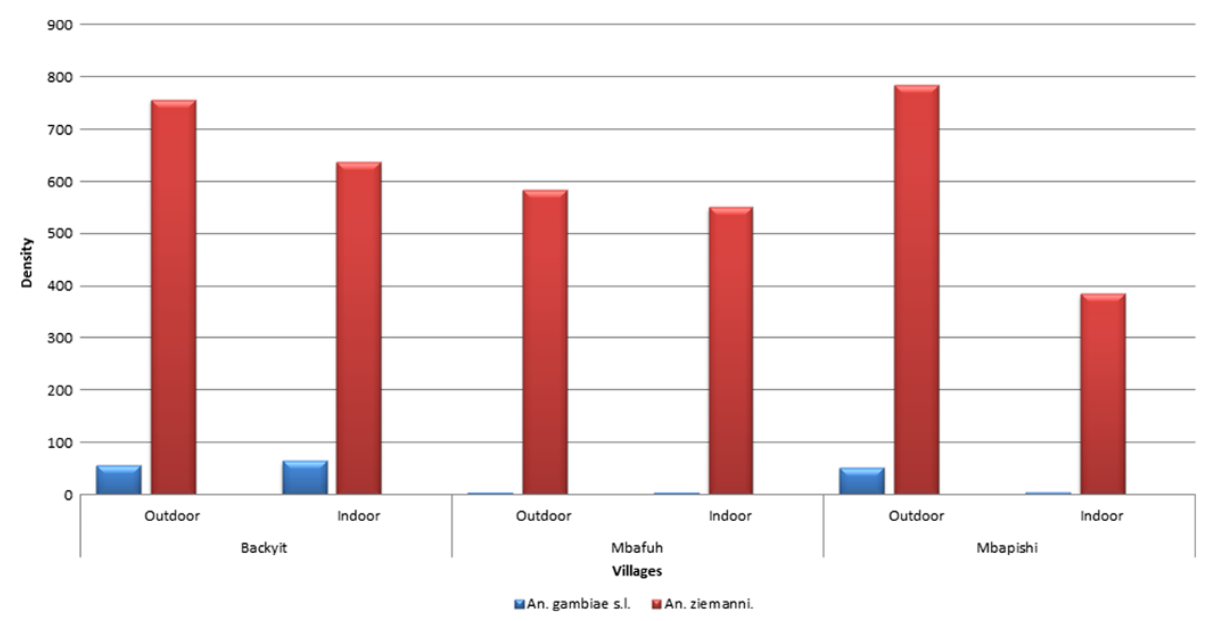

Figure 4 Biting behavior of An. ziemanni and An. gambiae in Backyit, Mbafuh and Mbapishi.

role in the transmission of malaria in several eco-epidemiological settings of Cameroon [5,29]. An. gambiae s.l generally known to be the main malaria vector in most areas of the southern forested parts of the country [30,31] was found in low numbers played only minor secondary role in malaria transmission in Ndop. Although Ndop is situated in the mid-western highlands that paves into the northern savannah regions, no An. arabiensis was found. Only An. gambiae s.s, M molecular form was found in the three villages corroborating with as previously reported finding in other forested areas of African $[4,32,33]$. This species is also the most widespread and major malaria vector in Cameroon and elsewhere in Africa [8,25,34-39].

The study revealed very high parity rates within the anopheline populations, implying that the vectors survive long enough to support the extrinsic sporogonic cycle of Plasmodium and therefore are able to transmit and even re-transmit malaria after several cycles of feeding on humans. Considering the good LLIN coverage (about 67.3\%), this might have led to a change in the vector behavior becoming more exophilic and thus escaping the LLIN. This in part might have contributed to the apparently high parity rates. The Culicidae nuisance is provided mainly by the Aedes, Coquillettidia, Culex, and Mansonia species. The breeding sites created by pigs in nearby households particularly favored the proliferation of the culicines.

\section{Conclusion}

Environmental pressures and climate change bring about malaria vectors dynamism, which leads to some malaria vectors becoming more efficient in transmitting malaria [40]. As a perfect illustration of this vector dynamism, it seems that An. ziemanni could sustain the transmission of malaria on its own in Ndop health district even in the absence of An. gambiae s.l, a major vector species in most parts of the country. Pending further investigation, these results provide useful baseline information on the heterogeneity in anopheline species composition and distribution maps that should be taken into account in vector control operations in Cameroon.

\section{Competing interests}

The authors declare that they have no competing interests.

\section{Authors' contributions}

EF conceived and planned the study and its design. RNT, TN, SP, JA, FT monitored the field and laboratory studies, analyzed and interpreted the data. RT, JB, EF, RL drafted the manuscript and, BF involved in the coordination of the laboratory studies and was involved in field and laboratory work for acquisition. JB assisted in the molecular and infectivity analyses. JB, EF and RL critically read the manuscript. All authors read and approved the final manuscript.

\section{Acknowledgements}

This work received financial assistance from UNICEF/UNDP/WORLD BANK WHO Special Programme for Research and Training Tropical Diseases

(TDR)/Business Line on Innovative Vector Control Interventions $N^{\circ}: 80361$. We are indebted to the authorities of the Ndop health District, the population and study participants in Ndop (Bambalang, Balikumbat and Bamessing) for the frank collaboration. We thank the research team of the Molecular parasitology and disease vector research Laboratory at the Biotechnology Center of Yaounde I University.

\section{Author details}

'National Reference Unit for Vector Control, The Biotechnology Center, University of Yaoundé I, P.O. Box 3851-Messa, Yaoundé, Cameroon. 'Faculty of Science, Department of Biochemistry, University of Yaoundé I, P.O. Box 812, Yaoundé, Cameroon. ${ }^{3}$ Ministry of Public Health, National Malaria Control Programme, P.O. Box 14386, Yaoundé, Cameroon.

Received: 15 March 2014 Accepted: 24 May 2014

Published: 5 June 2014 


\section{References}

1. WHO (World Health Organization): World malaria report 2012. Geneva: World Health Organization; 2012. http://www.who.int/iris/bitstream/10665/78945/ 1/9789241564533_eng.pdf?ua=1.

2. Programme National de Lutte contre le Paludisme-Cameroun: Plan stratégique du Cameroun 2011-2015. 27p; 2012.

3. Quakyi IA, Leke RG, Befidi-Mengue R, Tsafack M, Bomba-Nkolo D, Manga L, Tchinda V, Njeungue E, Kouontchou S, Fogako J, Nyonglema P, Harun LT, Djokam R, Sama G, Eno A, Megnekou R, Metenou S, Ndoutse L, Same-Ekobo A, Alake G, Meli J, Ngu J, Tietche F, Lohoue J, Mvondo JL, Wansi E, Leke R, Folefack A, Bigoga J, Bomba-Nkolo C, et al: The epidemiology of Plasmodium falciparum malaria in two Cameroonian villages: Simbock and Etoa. Am J Trop Med Hyg 2000, 63:222-230.

4. Coetzee $M$, Craig M, le Sueur D: Distribution of African malaria mosquitoes belonging to the Anopheles gambiae complex. Parasitol Today 2000, 16:74-77.

5. Antonio-Nkonjio C, Kerah CH, Simard F, Awono-Ambene P, Chouaibou M, Tchuinkam T, Fontenille D: Complexity of malaria vectorial system in Cameroon: contribution of secondary vectors to malaria transmission. J Med Entomol 2006, 43:1215-1221.

6. Fontenille D, Simard F: Unraveling complexities in human malaria transmission dynamics in Africa through a comprehensive knowledge of vector populations. Comp Immunol Microbiol Infect Dis 2004, 27:357-375.

7. Tchuinkam T, Simard F, Lélé-Defo E, Téné-Fossog B, Tateng-Ngouateu A, Antonio-Nkondjio C, Mpoame M, Toto JC, Njine T, Fontenille D, Awono-Ambéné HP: Bionomics of Anopheline species and malaria transmission dynamics along an altitudinal transect in Western Cameroon. Infect Dis 2010, 10:1-12.

8. Fondjo E: Etude du comportement du complexe Anopheles gambiae et de la transmission du paludisme dans deux faciès éco-climatique au Mali et au Cameroun. 93rd edition. Université de Bamako: Thèse de 3ème Cycle; 1996.

9. Ayala D, Costantini C, Ose K, Kamdem GC, Antonio-Nkondjio C, Agbor JP, Awono-Ambene HP, Fontenille D, Simard F: Habitat suitability and ecological niche profile of major malaria vectors in Cameroon. Malar J 2009, 8:307.

10. Hervy JF, Le Goff G, Geoffroy B, Herve JP, Manga L, Brunhes J: Les Anophèles de la région afro tropicale. Paris: France; 1998.

11. Brunhes J, Le Goff G, Bousses P, Anophèles afrotropicaux. V: Description du mâle et des stades pré-imaginaux d'An. deemingi et description d'An. eouzanin.sp. (Diptera: Culicidae). Ann Soc Entomol France 2003, 39:179-185.

12. Awono-Ambene HP, Kengne P, Simard F, Antonio-Nkondjio $C$ Fontenille D: Description and bionomics of Anopheles (Cellia) ovengensis (Diptera: Culicidae), a new malaria vector species of the Anopheles nili group from south Cameroon. J Med Entomol 2004, 41:561-568.

13. Manga $L$, Bouchite $B$, Toto JC, Froment A: La faune anophélienne et la transmission du paludisme dans une zone de transition forêt/savane au centre du Cameroun. Bull Soc Pathol Exot 1997, 90:128-130.

14. Robert V, Broek A, Stevens P, Slootweg R, Petrarca V, Coluzzi M, Le Goff G, Di Deco MA, Carnevale P: Mosquitoes and malaria transmission in irrigated rice-fields in the Benoue valley of northern Cameroon. Acta Trop 1992, 52:201-204.

15. Fontenille D, Wandji S, Djouaka R, Awono-Ambene HP: Anopheles hancocki, vecteur secondaire du paludisme au Cameroun. Bull Lia Doc OCEAC 2000, 33:23-26.

16. Antonio-Nkondjio C, Simard F, Awono-Ambene P, Ngassam P, Toto JC, Tchuinkam T, Fontenille D: Malaria vectors and urbanization in the equatorial forest region of south Cameroon. Trans R Soc Trop Med Hyg 2005, 99:347-354.

17. Cohuet A, Simard F, Toto JC, Kengne P, Coetzee M, Fontenille D: Species identification within the Anopheles funestus group of malaria vectors in Cameroon and evidence for a new species. Am J Trop Med Hyg 2003, 69:200-205

18. Gillies MT, De Meillon B: The Anophelinae of Africa South of the Sahara. 54th edition. Johannesburg: Publication of the South African Institute for Medical Research; 1968.
19. Gillies MT, Coetzee M: A Supplement to the Anophelinae of Africa South of the Sahara (Afrotropical region). 55th edition. Johannesburg: Publication of the South African Institute for Medical Research; 1987.

20. Detinova TS: Age grouping methods in Diptera of medical importance, with special reference to some vectors of malaria. WHO Monogr Series 1962, 47:216.

21. Burkot TR, Williams JL, Schneider I: Identification of Plasmodium falciparum infected mosquitoes by a double antibody enzyme linked immunosorbent assay. Am J Trop Med Hyg 1984, 33:783-788.

22. Fanello C, Santolamazza F, Della TA: Simultaneous identification of species and molecular forms of the Anopheles gambiae complex by PCR-RFLP. Med Vet Entomol 2002, 16:461-464.

23. Collins FH, Mendez MA, Rasmussen MO, Mehaffey PC, Besansky NJ, Finnerty V: A ribosomal RNA gene probe differentiates member species of the Anopheles gambiae complex. Am J Trop Med Hyg 1987, 37:37-41.

24. Favia GA, Della T, Bagayoko M, Lanfrancotti A, Sagnon NF, Touré YT, Coluzzi M: Molecular identification of sympatric chromosomal forms of Anopheles gambiae and further evidence of their reproductive isolation. Insect Mol Biol 1997, 6:377-383.

25. Bigoga JD, Manga L, Titanji VPK, Coetzee M, Leke RGF: Malaria vectors and transmission dynamics in the coastal south-western Cameroon. Malar J 2007, 6:5

26. Henry MC, Rogie C, Nzeyimana I, Assi SB, Dossou-Yovo J, Audibert M, Mathonnat J, Keundjian A, Akodo E, Teuscher T, Carnevale P: Inland valley rice production systems and malaria infection and disease in the savannah of Côte d'Ivoire. Trop Med Int Health 2003, 8:449-458.

27. Kamau L, Mulaya N, Vulule JM: Evaluation of Potential Role of Anopheles ziemanni in Malaria Transmission in Western Kenya. J Med Entomol 2006 43:774-776.

28. Maxwell CA, Msuya E, Sudi M, Njunwa KJ, Carneiro IA, Curtis CF: Effect of community-wide use of insecticide treated nets for 3-4 years on malaria morbidity in Tanzania. Trop Med Int Health 2002, 7:1003-1008

29. Bigoga D, Nanfack FM, Awono-Ambene PH, Patchoké S, Atangana J, Otia VS, Fondjo E, Moyou RS, Leke RGF: Seasonal prevalence of malaria vectors and entomological inoculation rates in the rubber cultivated area of Niete, South Region of Cameroon. Parasit Vectors 2012, 5:197.

30. Fondjo E, Bigoga JD, Leke RGF, Patchoke S, Kollo B, Dao A, Golenda C, Wirtz RA, Quakyi IA: Malaria transmission in Far Northern Cameroon: characterization of anopheline species and the sporozoite infection rate. J Cam Acad Sc 2002, 2:221S-226S

31. Antonio-Nkondjio C, Atangana J, Ndo C, Awono-Ambene P, Fondjo E, Fontenille $D$, Simard F: Malaria transmission and rice cultivation in Lagdo, northern Cameroon. Trans R Soc Trop Med Hyg 2008, 102:352-359.

32. Manga L, Toto JC, Le Goff G, Bhrunhes J: The bionomics of Anopheles funestus and its role in malaria transmission in a forested area of southern Cameroon. Trans R Soc Trop Med Hyg 1997, 91:387-388.

33. Wanji S, Tanke T, Atanga NS, Ajonina C, Tendongfor N, Fontenille D: Anopheles species of the mount Cameroon region: biting habits, feeding behaviour ant entomological inoculation rates. Trop Med Int Health 2003, 8:643-649.

34. Lengeler C, De Savigny D, Cattani J: Un mur contre la malaria: du nouveau dans la prévention des décès dus au paludisme. Ottawa, Canada: CRDI/OMS; 1997:207.

35. Lindblade KA, Walker ED, Onapa AW, Katungu J, Wilson ML: Highland malaria in Uganda: prospective analysis of an epidemic associated with El Nino. Trans R Soc Trop Med Hyg 1999, 93:480-487.

36. ljumba JN, Lindsay SW: Impact of irrigation on malaria in Africa: paddies paradox. Med Vet Entomol 2001, 15:1-11.

37. Jambou R, Ranaivo L, Raharimalala I: Malaria in the highlands of Madagascar after five years in indoors spraying of DDT. Trans $R$ Soc Trop Med Hyg 2001, 95:14-18.

38. Keiser J, Caldas de Castro M, Maltese MF, Bos R, Tanner M, Sanger BH, Utzinger $\mathrm{J}$ : The effect of irrigation and large dams on the burden of malaria on global and regional scale. Am J Trop Med Hyg 2004, 72:392-406 
39. Okollo PE, Bortel WV, Byaruhanga AM, Correwyn A, Roelants $P$, Talisuna A, D'alessandro U, Coosemans M: Variation in malaria transmission intensity in seven sites throughout Uganda. Am J Trop Med Hyg 2006, 75:219-225.

40. Zhou G, Minakawa N, Githeko AK, Yan GY: Association between climate variability and malaria epidemics in the East African highlands. Proc Natl Acad Sci U S A 2004, 101:2375-80.

doi:10.1186/1756-3305-7-262

Cite this article as: Tabue et al: Anopheles ziemanni a locally important malaria vector in Ndop health district, north west region of Cameroon. Parasites \& Vectors 2014 7:262.

\section{Submit your next manuscript to BioMed Central and take full advantage of:}

- Convenient online submission

- Thorough peer review

- No space constraints or color figure charges

- Immediate publication on acceptance

- Inclusion in PubMed, CAS, Scopus and Google Scholar

- Research which is freely available for redistribution 